\title{
The structure and stability of the uranium minerals, metatorbernite and metazeunerite, at high temperature
}

\author{
FIONA MACIVER- JONES ${ }^{1}$, CAROLINE KIRK ${ }^{2}$ AND \\ MARGARET GRAHAM ${ }^{3}$ \\ ${ }^{1}$ University of Edinburgh, School of Chemistry \\ ${ }^{2}$ University of Edinburgh \\ ${ }^{3}$ University of Edinburgh, School of Geoscience \\ Presenting Author: fmacive2@ed.ac.uk
}

Metatorbernite $\left(\mathrm{Cu}\left(\mathrm{UO}_{2}\right)_{2}\left(\mathrm{PO}_{4}\right)_{2} \cdot 8 \mathrm{H}_{2} \mathrm{O}\right)$ and metazeunerite $\left(\mathrm{Cu}\left(\mathrm{UO}_{2}\right)_{2}\left(\mathrm{AsO}_{4}\right)_{2} \cdot 8 \mathrm{H}_{2} \mathrm{O}\right)$ are common secondary uranium minerals that incorporate the highly soluble $\mathrm{U}(\mathrm{VI})$ ion into the solid phase. These minerals can therefore prevent the spread of aqueous $\mathrm{U}(\mathrm{VI})$ throughout the environment. The induced precipitation of metatorbernite using permeable reactive barriers is consequently being explored as a remediation strategy for $\mathrm{U}(\mathrm{VI})$-containing waste and contamination $[1,2]$. However, a better understanding of the mineral stability is required before this remediation strategy can be implemented, and in order to prevent the (re)release of U(VI) into the environment.

Metatorbernite and metazeunerite are autunite-group minerals comprised of uranyl phosphate/arsenate sheets with hydrated interlayers that contain water coordinated $\mathrm{Cu}$ (II) ions. When the minerals are heated from RT to $315^{\circ} \mathrm{C}$, they undergo a stepwise dehydration which coincides with a major reconstruction of the uranyl phosphate/arsenate sheets [3]. Water plays a key role in their structural stability. However, due to the dominant X-ray scattering of uranium atoms, previous $\mathrm{X}$-ray diffraction studies have been unable to identify how water is structurally incorporated into the partly dehydrated, high temperature phases. We have carried out a neutron powder diffraction study over the temperature range RT to $450^{\circ} \mathrm{C}$ on deuterated samples to investigate the structures of the parent metatorbernite/metazeunerite phases and the partly dehydrated, high temperature phases. As neutrons interact with atomic nuclei rather than electron density, their scattering length is not a function of atomic size; neutrons can therefore be used to locate light deuterium and oxygen atoms that comprise water molecules in the mineral structure.

Here, we present new structural models for the high temperature phases obtained through neutron powder diffraction and show that metatorbernite and metazeunerite both undergo different dehydration and thermal reconstruction pathways. We will discuss how these differences relate to their stability, with the ultimate aim of determining the most effective way to ensure $\mathrm{U}(\mathrm{VI})$ remains locked-up within the mineral phases.

[1] Bronstein (2005), US Environ. Prot. Agency.

[2] Szenknect, Mesbah, Descostes, Maihatchi-Ahamed, Bonato, Massonnet, Ziouane, Vors, Vercouter, Clavier, Lautru \& Dacheux (2020), Hazard. Mater., 392, 122501.

[3] Stubbs, Post, Elbert, Heaney \& Veblen (2010), Am. Mineral., 95, 1132-1140. 